\title{
Improved radiation risk models applied to different patient groups in Sweden
}

\author{
M. Andersson' ${ }^{1}$, K. Eckerman ${ }^{2}$, D. Pawel ${ }^{3}$, A. Almén 1 , S. Mattsson ${ }^{1}$ \\ ${ }^{1}$ Medical Radiation Physics, Department of Translational Medicine, Malmö, Lund University, Sweden \\ ${ }^{2}$ Center for Radiation Protection Knowledge, Oak Ridge National Laboratory, Oak Ridge, TN, USA \\ ${ }^{3}$ U.S. Environmental Protection Agency, Washington, USA
}

In radiological diagnostics and therapy, it is important that practitioners, referrers, (i.e. radiologists, radiation oncologists and others in health-care) are aware of how much radiation a patient may receive from the various procedures used and associated health risk. The profession has a duty to inform patients or their representatives of the advantages and disadvantages of specific investigations or treatment plans. The need to estimate and communicate risks in connection with medical use of ionizing radiation is highlighted e.g. in the Russian Federation State Law No 3, \$17.2, 1996 and in the EU directive (2013/59/EURATOM 2014). The most commonly used way to express harm in relation to low doses of ionizing radiation is use of the quantity effective dose (E). Effective dose, a radiation protection quantity, however is not intended to provide risk estimates for medical exposures. Its purpose is to optimize conditions for radiation workers (18-65 years) or the general public; all groups with age distributions that differ from patients. In this paper the lifetime attributable risk was used to estimate the excess risk of receiving and dying of radiogenic cancer. The lifetime attributable risk estimations are generated from three different variables, gender, attained age and age at exposure giving the possibility to create age and gender specific cancer risk estimations. Initially, the US Environmental Protection Agency lifetime attributable risk coefficients which are intended to predict the cancer risk from ionizing radiation to a normal US population were applied. In this work, the lifetime attributable risk predictions were modified to the normal Swedish population and to cohorts of Swedish patients undergoing radiological and nuclear medicine examinations or treatments with survival times that differ from the normal population. For Swedish males, all organs were given the same absorbed dose, exposed at 20, 40 and 70 years, the lifetime attributable risk coefficients $\left(G y^{-1}\right)$ were $0.11,0.068$, and 0.038 , respectively, which is lower than the corresponding figures for US males, 0.13, 0.077 , and 0.040. For Swedish females, all organs were given the same absorbed dose, exposed at 40 years of age with a diagnosis of breast, colon or liver cancer, the lifetime attributable risk coefficients are 0.064, 0.034, and 0.0038, respectively, which is much lower than if a 40 years female without known cancer is exposed, 0.073.

Key words: effective dose, life time attributable risk, radiation risk predictions.

\section{Улучшенные модели оценки радиационного риска для отдельных когорт пациентов в Швеции}

\footnotetext{
М. Андерссон ${ }^{1}$, К. Эккерман², Д. Павел³, А. Олмен ${ }^{1}$, С. Маттссон ${ }^{1}$

${ }^{1}$ Группа медицинской физики отдела трансляционной медицины Лундского университета, г. Мальмё, Университетский госпиталь округа Скона, Швеция

${ }^{2}$ Центр данных по радиационной защите, Национальная лаборатория Ок-Ридж, Ок-Ридж, Теннесси, США

${ }^{3}$ Агентство по защите окружающей среды США, Вашингтон, округ Колумбия, США

В лучевой диагностике и терапии крайне важно, чтобы медицинский персонал (врачи-рентгенологи, лечащие врачи, радиационные онкологи и пр.) имели представление о том, какую дозу облучения получил пациент от различных рентгенорадиологических исследований и с каким риском для здоровья эта доза связана. Медицинский персонал несет ответственность за информирование пациентов и их законных представителей о достоинствах и недостатках выбранных исследований или планов лечения. Так, например, необходимость оценки и коммуникации рисков в контексте использования ионизирующего излучения в медицине особо отмечена в Федеральном законе Ф3-3 «О радиационной безопасности населения» в Россйской Федерации и в директиве Евросоюза 2013/59/EURATOM 2014. Наиболее распространенным способом выражения вреда от низких доз ионизирующего излучения является использование эффективной дозы, которая, хотя и является основной величиной в радиационной защите, не предназначена для оценки рисков от медицинского
}

\section{Mattsson Sören}

Medical Radiation Physics Malmö

Address for correspondence: ITM, Lund University, Skåne University Hospital Malmö, SE-205 02 Malmö, Sweden; E-mail: soren.mattsson@med.lu.se 
облучения. Ее задачей является обеспечение оптимизации радиационной защиты персонала (людей в возрасте 18-65 лет) и населения - групп с возрастным распределением, резко отличающимся от возрастных распределений пациентов. В данном исследовании величина пожсизенного атрибутивного риска была использована для оценки избыточного риска получить и умереть от радиогенного рака различной нозологии. Оценки значений пожизненного атрибутивного риска основывались на трех переменных: пол, возраст дожития и возраст при облучении, что позволило определить риски развития радиогенного рака с учетом пола и возраста пациентов. Изначально были использованы коэффициенты пожизненного атрибутивного риска, разработанные Агентством по защите окружающей среды США, которые позволяют оценить избыточные радиогенные раки для нормальной популяции США. В данной работе значения коэффициентов пожсизненного атрибутивного риска были изменены с учетом специфики здорового шведского населения, а также когорт шведских пациентов, проходящих различные рентгенорадиологические исследования и курсы лучевой терапии, время дожития которых существенно отличалось от такового для обычного населения. Для шведских мужчин, при условии, что все органы организма получили одну и ту же поглощенную дозу и облучение произошло в возрасте 20, 40 и 70 лет, соответствующие коэффициенты пожизненного атрибутивного риска (Гр $\left.{ }^{-1}\right)$ составили 0,11, 0,068, и 0,038 соответственно, что ниже по сравнению с аналогичными данными для американских мужчин - 0,13, 0,077, и 0,040 соответственно. Для шведских женщин, при условии, что все органы организма получили одну поглощенную дозу и облучение произошло в возрасте 40 лет с диагнозом рака груди, прямой кишки или печени, коэффициенты пожизненного атрибутивного риска $\left(\Gamma p^{-1}\right)$ составили 0,064, 0,034, и 0,0038 соответственно, что существенно ниже значения 0,073 в случае облучения 40-летних женщин, у которых диагноз рака установлен не был.

Ключевые слова: эффективная доза, пожизненный атрибутивный риск, оценка радиационного риска.

\section{Introduction}

In radiological diagnostics and therapy, it is important that practitioners, referrers, radiologists, radiation oncologists and others in health-care understand how much radiation a patient may receive from the various procedures used and the associated risk. National and international directives state e.g. that "... based on the citizens' or patients' request they shall receive full information on expected or received dose and possible consequences due to the $x$-ray examination ..." (Russian Federation State Law No 3, § 17.2 "On the radiation safety of the public, 1996") [1] and the need to "... ensure wherever practicable and prior to the exposure taking place adequate information relating to the benefits and risks associated with the radiation dose from the medical exposure" (EU directive 2013/59/EURATOM 2014) [2].

The most commonly used way to express harm in relation to low doses of ionizing radiation is to use the quantity effective dose (E) defined by the International Commission on Radiological Protection (ICRP) [3]. However, effective dose was not intended to provide risk estimates for medical exposures. Its purpose is to optimize conditions for radiation workers (18-65 years) or the general public - groups with different age distributions than patients. In spite of that, effective dose is also frequently used for risk estimates for patients undergoing medical exposures and even for individual patients. The effective dose is a weighted sum of tissue specific doses. ICRP [3] determined tissue weights by first calculating tissue-specific "nominal risks adjusted for lethality and quality of life" which are the tissue-specific cancer (and hereditary) risk estimates multiplied by a "lethality fractions", and "relative cancer free life lost". The tissue weights were then subjectively rounded and normalized to sum to 1 , resulting in values of $0.01,0.04,0.08$, or 0.12 . Based on estimates of detriment for lifetime exposure to uniform whole-body radiation, ICRP established risk coefficients of $5.5 \%$ per $S v$ for a population of all ages and $4.1 \%$ per $S v$ for radiation workers. The effective dose is a robust unit for many populations exposed to environmental and occupational sources of radiation, but it does not

\section{Введение}

В лучевой диагностике и терапии крайне важно, чтобы медицинский персонал (врачи-рентгенологи, лечащие врачи, радиационные онкологи и пр.) имел представление о том, какую дозу облучения получил пациент от различных рентгенорадиологических исследований и с каким радиационным риском для здоровья эта доза связана. Это условие является обязательным в соответствии с различными национальными и международными законодательными актами. Так, в российском Федеральном законе № 3-Ф3 «О радиационной безопасности населения» прописано, что «По требованию гражданина (пациента) ему предоставляется полная информация об ожидаемой или о получаемой им дозе облучения и о возможных последствиях при проведении медицинских рентгенорадиологических процедур». Директива Евросоюза 2013/59/EURATOM 2014 предусматривает необходимость предоставления адекватной информации о пользе и рисках от доз медицинского облучения перед проведением исследования.

Наиболее распространенной мерой вреда от низких доз ионизирующего излучения является эффективная доза (ЭД), определенная Международной комиссией по радиологической защите (МКРЗ). Однако эффективная доза не была предназначения для оценки риска от медицинского облучения. ЭД использовалась для оптимизации условий работы персонала (в возрасте 18-65 лет) или населения - групп с иными возрастными распределениями по сравнению с пациентами. Несмотря на данные ограничения, ЭД часто используется для оценки риска у пациентов при медицинском облучении, в том числе и для индивидуальных пациентов. Эффективная доза является взвешенной суммой тканеспецифичных доз. МКРЗ определило взвешивающие коэффициенты путем расчета тканеспецифичных «номинальных рисков с поправкой на смертность и качество жизни», которые представляют собой тканеспецифичные оценки риска рака (и наследственных эффектов), умноженные на «доли летальности» и «относительную потерю лет жизни без рака». Данные 
take age and sex into account (e.g., for specific individuals undergoing medical procedures). The reason for this, stated by the ICRP, is that the system of protection should be sufficiently simple and robust $[3,4]$.

A step forward, as it relates to specific patients, could be to define an "index of harm" as the effective dose (keeping the tissue weighting factors) multiplied by a relative risk factor which is age dependent. Almén and Mattsson [5] used a risk factor between 2 and 3 for children and adolescents and Wall et al., [6], Balonov and Shrimpton [7] and Balonov et al. [8] a relative risk factor of 2 for children and adolescents $<18 \mathrm{y}, 1$ for adults $<65$ y and 0.1 for seniors $65+$ years. Simple adjustments of ICRP's nominal risk coefficient to account for age differences have in this way made effective dose a useful tool for the description of the radiation detriment.

An alternative approach to effective dose is to base risk assessments directly on calculations of lifetime attributable risk $(L A R)$. There are different organizations performing risk models for assessing LAR $[9,10]$. For these calculations, we adopted the approach used by the United States' Environmental Protection Agency (EPA) [9]. For most cancer sites, the EPA risk models and other underlying assumptions are identical to those recommended in the United States' National Research Council BEIR VII report [11]. For example, the models for most cancers were derived from incidence data from the Lifespan Study of the Japanese atomic bomb survivors and a dose and dose rate effectiveness factor of 1.5 assumed for cancers other than leukemia, bone, and skin. Extensions and modifications to the BEIR VII approach include risk estimates for alpha particles and a more extensive analysis of uncertainties associated with the radiogenic risk estimates. These risk models are used to assess both excess risk of cancer incidence and premature cancer death. For most cancer sites, the EPA assumed both relative and absolute excess risk to be proportional to the absorbed dose with a slope that depends on the tissue, age at exposure, attained age and sex. An important exception is leukemia, for which risk depends also on time since exposure.

In a previous analysis [12] we used EPA LAR coefficients as an alternative to effective dose - to quantify sex and age specific cancer risks for patients undergoing $x$-ray examinations, nuclear medicine examinations and treatments. The study also assessed differences in outcome between effective dose and $L A R$ risk estimation, as illustrated in Fig. 1. The effective dosebased risk for adults $(4.1 \%$ per $S v)$ and the $L A R$ risk are presented for a ${ }^{99 \mathrm{~m}} \mathrm{Tc}$ bone scintigraphy, for ages at exposure between 0 and 110 years. We also showed that if the difference in cancer risk for different ages at exposure and sex is known, it is possible to perform bone scintigraphy procedures with the same risk for stochastic effects by varying the activity administered for patients of different age and sex. However, for that study, the $L A R$ coefficients that were applied had been developed for a standard (healthy) US population. The aim of the current project was to explore the need to modify the approach by applying $L A R$ coefficients that are appropriate for a standard Swedish population and also for specific cohorts of Swedish patients.

\section{Materials and Methods}

\subsection{Investigated cohorts of patients in medicine}

The cohorts of patients range from diagnostic radiology/ subject - especially those examined using computed tomography $(\mathrm{CT})$ - to cohorts of patients undergoing nuclear medicine взвешивающие коэффициенты были затем округлены и нормализованы к сумме в 1 , что позволило получить значения $0,01,0,04,0,08$, или 0,12. На основе оценки вреда от равномерного облучения всего тела в течение всей жизни МКРЗ установило коэффициенты риска в размере 5,5\% на 1 Зв для населения всех возрастных групп и $4,1 \%$ на 1 Зв для персонала. Эффективная доза является надежной величиной для различных популяций, которые подвергаются природному и профессиональному облучению, но она не учитывает пол и возраст (например, для отдельных индивидуумов при медицинском облучении). Это объясняется тем, что, согласно МКРЗ, система радиационной защиты должна быть простой и надежной.

Развитием данной системы, применительно к отдельным категориям пациентов, является определение «индекса вреда», путем умножения эффективной дозы (с сохранением текущих взвешивающих коэффициентов) на возраст-зависимый относительный коэффициент риска. B работах Almén и Mattsson [5] были использованы коэффициенты риска в диапазоне 2-3 для детей и подростков; Wall и др., [6], Balonov и Shrimpton [7] и Balonov и др. [8] использовали коэффициенты риска равные 2 для детей и подростков (до 18 лет), 1 для взрослых (18-65 лет) и 0,1 для лиц старше 65 лет. Простые коррекции номинального коэффициента риска МКРЗ с учетом различий в возрасте превращают эффективную дозу в полезный инструмент для описания радиационного вреда (риска).

Альтернативой эффективной дозе является использование показателей риска - например, пожизненного атрибутивного риска (LAR). Разработкой моделей для расчета LAR занимается целый ряд организаций. Для задач данной работы был использован подход Агентства по защите окружающей среды США (ЕРА). Для большинства локализаций рака, модели риска ЕРА и базовые предположения являются идентичными представленным в отчете Национального научного совета США BEIR VII. Для примера, модели для большинства раков были разработаны на базе данных по заболеваемости из пожизненных исследований на японской когорте выживших после атомных бомбардировок (так называемой LSS-когорте); для всех раков, кроме лейкемий, раков кожи и костей, были приняты коэффициенты эффективности дозы и мощности дозы, равные 1,5. Дополнения и модификации к отчету BEIR VII включают оценку риска для альфа-частиц и более детальный анализ неопределенностей, ассоциированных с оценкой радиационного риска. Данные модели риска используются как для оценки избыточного риска заболеваемости раком, так и для преждевременной смерти от рака. Для большинства локализаций рака ЕРА предположила, что как относительный, так и абсолютный избыточный риск пропорциональны поглощенной дозе с наклоном, который определяется тканью, возрастом на момент облучения, возрастом дожития и полом. Исключением является лейкемия, для которой риск зависит также от времени, прошедшего с момента облучения.

В предыдущих анализах мы использовали значения пожизненного атрибутивного риска по модели ЕРА - в качестве альтернативы эффективной дозы - для количественной оценки специфичных по полу и возрасту рисков радиогенного рака для пациентов при проведении лучевой диагностики и терапии, процедур ядерной медицины. Также было показаны различия между расчетами на ос- 
and external beam radiation therapies. To properly assess the risk associated with medical procedures, one must consider the range of circumstances under which the radiation exposures occurred. CT examinations are administered to many patients for a wide range of medical indications. The purpose of the exposures is to provide information on the disease, (e.g., to exclude or stage disease) as part of treatment planning or as an aid in executing the treatment. Other exposures are performed to verify treatment results in connection with the treatment but also used to follow-up disease - sometimes up to several years after the actual treatment ends. Thus, medical exposures involve healthy (normal), diseased, and potentially cured persons (which are assumed to re-enter the cohort of healthy individuals), and for these three types of patient groups there are different sets of survival rates. Exposure levels can vary greatly, depending both on the type of examination and the hospital where the examination is performed.

For radiation treatments (e.g., therapy with radiopharmaceuticals and external beam radiation therapy) concern about acute radiation effects takes precedence and less interest is devoted to the mitigation of radiation induced cancer. Before an external beam radiation therapy treatment is performed the absorbed dose is planned, using a sophisticated dose planning calculation, and the dose distribution is optimized in the planning target volume, with attention to doses in tissues at risk for acute effects. Outside this volume, absorbed dose and radiation risk levels are to a less extent assessed and considered. However, larger volumes of healthy tissues are exposed to doses of varying magnitude in patients undergoing external beam radiation therapy [13]. Also, in nuclear medicine therapy, the absorbed dose distribution in the patient is not routinely assessed and the dose distribution for the individual patient is to a less extent optimized. Radiopharmaceuticals include both alpha and beta emitting radionuclides resulting in high doses to small volumes of tissues. However, organs outside targeted tissues can receive a high radiation absorbed dose resulting in acute radiation effects in some nuclear medicine procedures. нове эффективной дозы и LAR (рис. 1). На рисунке представлены результаты оценки риска на основе эффективной дозы для взрослых (4,1\% на Зв) и на основе LAR для сцинтиграфии костей с ${ }^{99 m}$ Тс для диапазона возрастов на момент облучения 0-110 лет. Также было показано, что при известных различиях в риске для различного возраста при облучении и поле возможно провести сцинтиграфию костей с одинаковым риском развития стохастических эффектов для пациентов различного пола и возраста за счет изменения вводимой активности. Однако использовались значения LAR для стандартного (здорового) населения США.

Цель исследования - анализ необходимости изменения подхода к оценке радиационных рисков путем применения значений LAR для стандартного шведского населения и для отдельных когорт шведских пациентов.

\section{Материалы и методы}

\section{Исследованные когорты пациентов при медицинском облучении}

В исследовании были использованы различные когорты пациентов: от проходящих стандартные рентгенографические исследования и особенно компьютерную томографию до проходящих исследования методами ядерной медицины и лучевую терапию. Для достоверной оценки риска, ассоциированного с медицинским облучением, необходимо учитывать обстоятельства, при которых данное облучение произошло. Например, КТ-исследования используются для различных пациентов для широкого диапазона клинических назначений. Целью исследования является предоставление информации о заболевании (исключить заболевание и правильно его стадировать) в качестве части планирования лечения или поддержки при проведении лечения. Другие исследования используются для подтверждения результатов лечения или для наблюдения за пациентов в стадии ремиссии - иногда вплоть до нескольких лет после окончания курса лечения. Таким образом, медицинское облучение включает в себя здо-
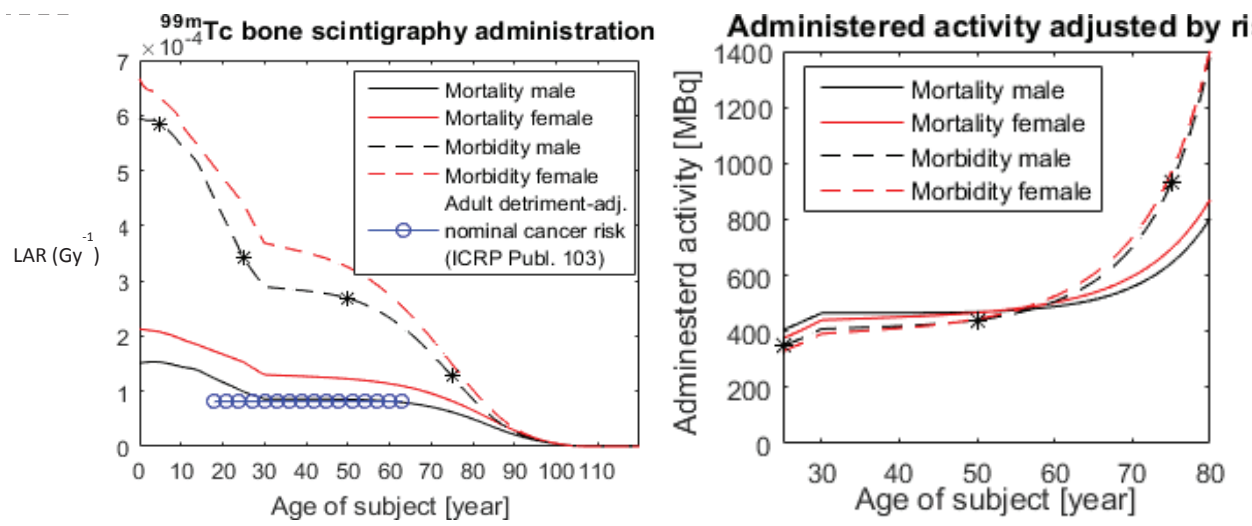

Fig. 1. Left: Age at exposure and sex dependent cancer morbidity and mortality risks from an intravenously administered ${ }^{99 m} \mathrm{Tc}$-phosphonates for bone scintigraphy using recommended age dependent administrations [12]. Right: Adjusted administered activity to get the same radiation risk independent of age and gender [12]

[Рис. 1. Слева: возраст при облучении и риски заболеваемости и смертности от рака с учетом пола пациента при внутривенном

введении ${ }^{99 m}$ Тс-фосфоната для сцинтиграфии костей с использованием рекомендованных активностей для соответствующих возрастных категорий. Справа: скорректированные значения активности данного препарата для достижения одного и того же риска вне зависимости от пола и возраста] 


\subsection{Risk estimates using $L A R$}

For cancer patients the lifetime attributable risk of a secondary primary cancer caused by radiation and the risk of dying of this cancer is estimated. The term "secondary primary cancer" describes, in this case, a new primary cancer that occurs in a person who has had cancer in the past. The second primary cancers may occur years after the original (primary) cancer was diagnosed and is independent of the first cancer. This is important as most radiation treatments for cancer involve many examinations. For non-cancer patients the LAR coefficients for estimating the morbidity and mortality risk for radiation induced primary cancer for 14 specific cancers: bone, breast, colon, kidney, leukaemia, liver, lung, ovary, prostate, skin, stomach, thyroid, urinary bladder, uterus; and the category 'residual site' cancers are available [9]. The residual site cancers include cancers for which there were insufficient data from the Life Span Study of Japanese Atomic Bomb Survivors or other epidemiological studies to reliably quantify radiogenic site-specific risks. The LAR cancer risk predictions for a specific cancer site are presented in Eq.1, which basically can be described in three steps. The first step is to calculate, for each of the 15 different cancer types, age specific excess rate of cancer diagnosis, $M(D, b, a)$. The $M(D, b, a)$ is a function of three variables, the absorbed dose (D) of the specific organ, the age (e) at the exposure and the attained age (a) of cancer diagnosis. The next step is to multiply the excess cancer rates by the probability of being alive at age a, S(a), each year after the exposure, normalized by the probability of being alive at exposure. Finally, the LAR is obtained by integrating these adjusted excess cancer rates though integration over attained age starting post a latent period of five years (two for leukemia) after the age of exposure. Thus,

$$
\operatorname{LAR}(D, e)_{\text {Sex }}=\int_{e+L}^{110} M(D, e, a) \cdot \frac{S(a)}{S(e+L)} d a(1)
$$

where $D$ is the absorbed dose, $e$ is the age (year) at exposure, $L$ is the latency period (year) after exposure for which stochastic effects occurs, $a$ is the attained age (year), $S(a)$ and $S(e)$ is the survival rate at age a and e respectively.

\subsection{Risk Modification of LAR}

Our radiogenic cancer risk projections are combinations of projections based on excess absolute risk (EAR) and excess relative risk (ERR). A projection based solely on an EAR model assumes that radiation risks for the "target" population is the same as for the Life-Span Study, whereas, a projection based solely on the ERR assumes risks are proportional to baseline cancer risks. The BEIR VII Committee concluded that "mechanistic considerations" suggested that for most cancer sites more emphasis should be placed on an ERR model. It can be noted that ICRP used equal weights for ERR and EAR models. The EPA [9], following the advice of the BEIR VII Committee, assigned a weight of 0.7 to the ERR model for most cancers. e.g. the EPA predicted excess cancer rate for male stomach cancer is:

$$
\begin{gathered}
M(D, e, a)_{I, \text { Male }(S t)}=0.7 *\left(\operatorname{ERR}(D, e, a)_{I, \text { Male }(S t)} * \lambda(a)\right)+ \\
+0.3 *\left(\operatorname{EAR}(D, e, a)_{I, \text { Male }(S t)}\right)(2)
\end{gathered}
$$

where $M(D, e, a)_{I, \text { Male }(S t)}$ is the excess incidence cancer risk, $\lambda(a)$ is the base line cancer risk at age a and the ERR ровых (нормальных), заболевших и возможно вылеченных индивидуумов (предполагается что данная категория в дальнейшем войдет в состав когорты здоровых); для всех этих категорий индивидуумов коэффициенты выживаемости существенно отличаются. Также существенно будут отличаться уровни облучения пациентов, в зависимости от типа исследования и материально-технического оснащения медицинской организации.

Для лучевой терапии (как для радионуклидной, так и для дистанционной терапии) в первую очередь актуально исключение детерминированных эффектов; оценке развития радиогенных раков уделяется меньше внимания. До проведения дистанционной терапии производится оценка поглощенной дозы с использованием комплексных алгоритмов; проводится оптимизация распределений доз в планируемом объеме лечения с учетом поглощенных доз в тканях, близких к уровню развития детерминированных эффектов. За пределами данной области оценка и учет поглощенных доз и уровней риска проводятся крайне редко. Однако большие объемы здоровых тканей облучаются различными дозами при проведении дистанционной лучевой терапии. Также в радионуклидной терапии крайне редко проводится оценка распределений поглощенных доз у индивидуальных пациентов. Радиофармпрепараты для радионуклидной терапии содержат альфа- и бетаизлучатели, что приводит к высоким дозам в небольших объемах ткани. Ткани за пределами органа-мишени могут получать высокие уровни поглощенной дозы, что будет приводить к развитию детерминированных эффектов.

\section{Расчет пожизненного атрибутивного риска}

Для онкологических пациентов оцениваются пожизненный атрибутивный риск развития «вторичного первичного рака» от облучения и риск смерти от данного рака. Термин «вторичный первичный рак» в данном случае относится к новому первичному раку, который возникает у индивидуума, у которого в прошлом уже был рак. Вторичный первичный рак может возникнуть спустя несколько лет после того, как исходный (первичный) рак был диагностирован; он развивается независимо от первого рака. Это является очень важным, так как большинство схем лучевой терапии рака предусматривают большое количество исследований с применением лучевой диагностики. Для нераковых пациентов доступны значения LAR для оценки заболеваемости и смертности от первичного радиогенного рака 14 локализаций: костная ткань, молочная железа, прямая кишка, лейкемия, печень, легкое, яичники, простата, кожа, желудок, щитовидная железа, мочевой пузырь, матка. Дополнительная категория «раки прочих локализаций» включает в себя раки, для которых было собрано недостаточно данных в пожизненных исследованиях на японской когорте выживших после атомных бомбардировок и прочих эпидемиологических исследованиях для достоверной количественной оценки радиационных рисков, специфичных для локализации. Расчет LAR для специфической локализации рака производится по формуле (1). Процедуру расчета LAR можно разбить на три этапа. Первый этап заключается в расчете возраст-специфичной избыточной частоты диагностики рака $M(D, e, a)$ для каждой из 15 локализаций. $M(D, e, a)$ является функцией трех переменных: поглощенной дозы в конкретном органе $D$, возраста на момент облучения (e) и 
and EAR are the two different cancer risk estimates of male stomach cancer for an absorbed stomach dose, at an age of exposure e and an attained age of a.

To apply the excess cancer risk on populations other than the U.S., the baseline cancer statistics for the ERR predictions should be changed. The LAR predictions published by the EPA [9] were recalculated for a Swedish population, based on survival rates from the Swedish National Board of Health and Welfare [14] and cancer statistics from NORDCAN [15]. It should also be noted that cancer risk projections shown in Fig 2. for environmental exposures are based on survival functions for normal populations. For specific populations of patients, e.g., patients suspected to have a life-shortening illness, the survival fraction $S(a)$ in eq. 1 often needs to be modified. For example, in the data analyzed by Critz et al. [16], the 10, 15, 20, and 25-year disease-free survival for prostate cancer treated with brachytherapy and external beam radiotherapy is $75 \%, 73 \%, 73 \%, 73 \%$, respectively. As the data indicates, no further recurrence was detected between 15 and 25 years, which indicates that no further follow up for this type of cancer is needed after 15 years to fully evaluate any prostate cancer treatment and that after 15 years patients can be treated as normal. These assumptions were used to estimate excess cancer risk for these patients, which will not follow the same survival rate as a normal population. The survival rates in the LAR equations has been modified with the longest time duration age and sex dependent cancer statistics data for the creation of population specific patient survival rates, as shown in Fig. 3. The EPA ERR and EAR models with Swedish survival rates in Fig. 3 were modified to account for the shorter expected survival for subpopulations of cancer patients as compared to survival rates for standard (relatively healthy) populations. This shows the effect modification of survival rates for different groups of cancer patients has on the predicted LAR. For calculating LAR, the EPA risk models were applied to survival rates and female incidence cancer data for three groups

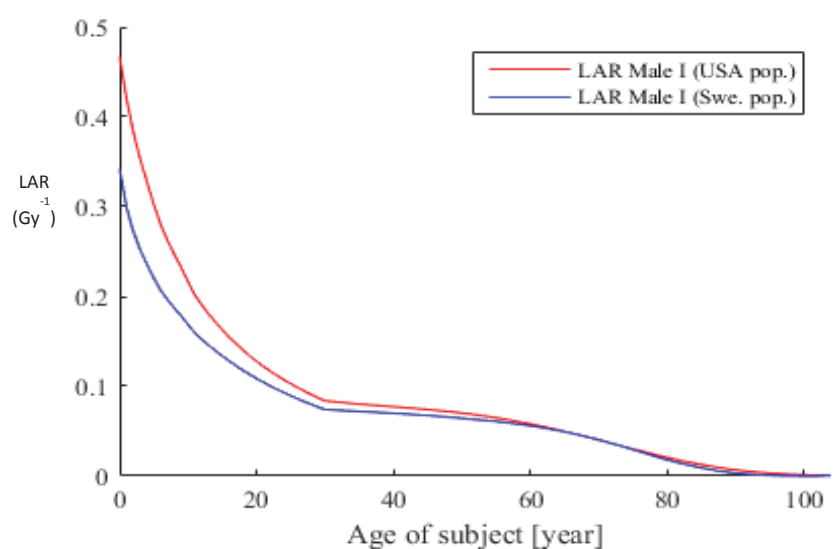

Fig. 2. LAR incidence as function of the age at exposure for a Swedish male population based on the last 30 years of Swedish cancer statistic [15] and a US male population both based on the risk prediction given by US EPA [9]. All organs are given the same absorbed dose.

[Рис. 2. Зависимость пожизненного атрибутивного риска от возраста при облучении для шведских мужчин по данным шведской онкостатистики за последние 30 лет [15] и

аналогичные данные для американских мужчин, основанные на оценке рисков по данным Агентства по защите окружающей среды [9]. Все органы получили одинаковую поглощенную дозу] достигнутого возраста на момент диагностирования рака (a). Следующим этапом является умножение избыточной частоты рака на вероятность дожития от рождения до возраста $a, S(a)$, нормализованную на вероятность быть в живых на момент облучения. И наконец, на третьем этапе пожизненный атрибутивный риск $L A R(D, e)_{\text {sex }}$ определяется путем интегрирования скорректированных избыточных частот рака по достигнутому возрасту в пределах от возраста на момент облучения с учетом латентного периода в 5 лет (2 года для лейкемии) до 110 лет. Таким образом,

$$
\operatorname{LAR}(D, e)_{S e x}=\int_{e+L}^{110} M(D, e, a) \cdot \frac{S(a)}{S(e+L)} d a(1)
$$

где $D$ - поглощенная доза; $e$ - возраст на момент облучения (лет); $L$ - латентный период после облучения (лет), после которого начнут проявляться стохастические эффекты; a - достигнутый возраст (лет); $S($ a) и $S($ e) - вероятности дожития до возрастов а и е соответственно.

\section{Модисрикация моделей для расчета пожизненного атрибутивного риска}

Наши модели риска радиогенного рака являются комбинацией моделей, основанных на избыточном абсолютном риске (EAR) и избыточном относительном риске (ERR). Модель, основанная исключительно на EAR, подразумевает, что радиационный риск для выбранной группы населения идентичен таковому для LSS-когорты. В свою очередь, модель, основанная на ERR, предполагает, что радиационный риск пропорционален фоновому уровню риска рака данной локализации в популяции. Комитет BEIR VII заключил, что для большинства локализаций рака целесообразно использовать модель ERR. Следует отметить, что МКРЗ использовала модели ERR и EAR с одинаковыми взвешивающими коэффициентами. EPA, в соответствии с рекомендациями Комитета BEIR VII, присвоила взвешивающий коэффициент, равный 0,7 модели ERR для раков большинства локализаций. Например, предсказанная избыточная частота развития рака желудка для мужчин составит

$$
\begin{gathered}
M(D, e, a)_{I, \text { Male }(S t)}=0.7 *\left(\operatorname{ERR}(D, e, a)_{I, \text { Male }(S t)} * \lambda(a)\right)+ \\
+0.3 *\left(\operatorname{EAR}(D, e, a)_{I, \text { Male }(S t)}\right)(2)
\end{gathered}
$$

где $M(D, e, a)_{I, M a l e(s t)}$ - избыточная частота заболеваемости раком желудка среди мужчин; $\lambda(a)$ - фоновый уровень заболеваемости раком желудка в возрасте a; $E R R$ и $E A R$ - два различных показателя избыточного риска развития рака желудка для мужчин при поглощенной дозе в желудке $D$ в возрасте на момент облучения $e$, рассчитанные для достигнутого возраста а.

Для применения избыточного риска развития рака для других (не американских) популяций необходимо использовать другие уровни фоновой заболеваемости раком в модели избыточного относительного риска ERR. Результаты расчетов пожизненного атрибутивного риска, опубликованные ЕРА, были пересчитаны для шведского населения, основываясь на вероятностях дожития, публикуемых Шведским национальным советом по здоровью и благополучию, и онкологической статистике 
of patients (i.e., healthy, breast, colon and liver). Here the survival rate for female breast cancer is high while the survival rate for liver cancer is low.

The survival rates in the LAR equations has been modified with the longest time duration age and sex dependent cancer statistics data for the creation of population specific patient survival rates. The probability of survival rate for age a is calculated as the number of persons alive at year a divided by the initial persons alive at age 0 . The patient specific survival rates, $S(a)_{\text {Pat.spec }}$ for e.g. liver are modified for the first five years after exposure as from:

$$
S(a)_{\text {Pat.Spec }}=\frac{N(a)^{*}}{N(0)}=\frac{N(a) * A S P_{5}(\text { liver })}{N(0)}
$$

where $N(a)$ and $N(0)$ are the total number of health sex specific person alive at age a and $0 . \mathrm{N}(\mathrm{a})^{*}$ is the total number of patients live at age a generated by multiplying $\mathrm{N}(\mathrm{a})$ with the annual 5-year survival probability of liver cancer patients. The results of three different cancer patients are shown in in Fig. 3. The EPA ERR and EAR models with Swedish survival rates in Fig. 3 were modified to account for the shorter expected survival for subpopulations of cancer patients as compared to survival rates for standard (relatively healthy) populations. This shows the effect modification of survival rates for different groups of cancer patients has on the predicted LAR. For calculating LAR, the EPA risk models were applied to survival rates and female incidence cancer data for three groups of patients (i.e., healthy, breast, colon and liver). Here the survival rate for female breast cancer is high while the survival rate for liver cancer is low.

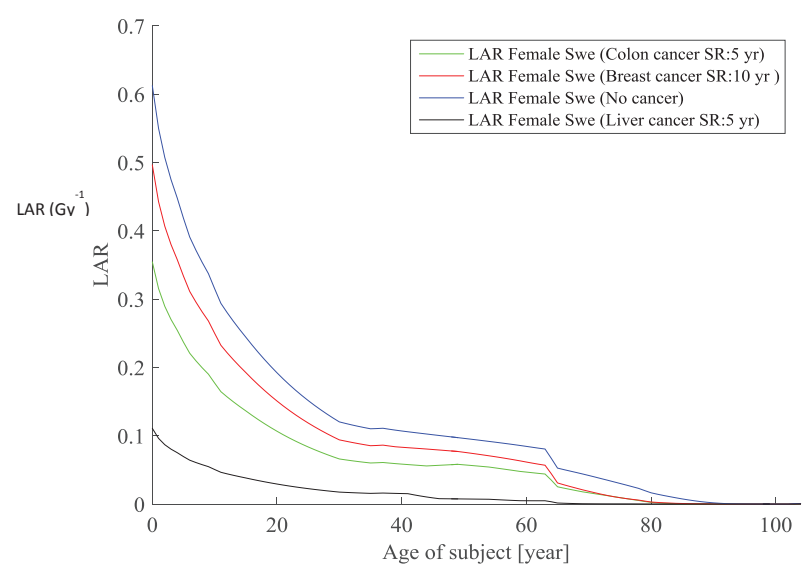

Fig. 3. LAR incidence as function of the age at exposure for a normal Swedish female population and for three different groups of Swedish female cancer patients (diagnosed with any stage of, and treated against colon cancer, breast cancer and liver cancer, respectively). SR means years of included survival rate. All organs were given the same absorbed dose.

[Рис. 3. Зависимость пожизненного атрибутивного риска от возраста при облучении для нормального (здорового) шведского населения и для трех различных групп шведских онкобольных женского пола (с установленным диагнозом или проходящих лечение при раке прямой кишки, молочной железы и печени). SR - годы учтённого периода дожития. Все органы получили одинаковую поглощенную дозу]
NORDCAN. Следует отметить, что значения показателя риска возникновения рака, представленные на рисунке 2 для фонового облучения, основаны на функциях выживания для нормального населения. Для специфических выборок пациентов (например, пациентов с заболеванием, которое существенно сократит срок жизни), вероятность дожития S(a) в выражении (1) зачастую должна быть модифицирована. Например, в данных, проанализированных Critz et al., 10-, 15-, 20- и 25-летняя выживаемость без заболевания для рака простаты после проведенного курса лечения с помощью брахитерапии и дистанционной лучевой терапии составила 75\%, 73\%, 73\%, 73\%, соответственно. Как показывают данные, никаких рецидивов не было выявлено между 15 и 25 годами; таким образом, после 15 лет наблюдения пациентов можно относить к группе здоровых. Данные предположения были использованы для оценки избыточного риска рака для таких пациентов, вероятности дожития которых отличаются от нормального населения. Вероятности дожития в выражении для расчета пожизненного атрибутивного риска были заменены на специфичные для популяции вероятности дожития для пациентов (рис. 3). Для этого была использована статистика по онкозаболеваемости среди различных половозрастных групп, охватывающая максимально продолжительный период времени. Модели ERR и EAR, разработанные EPA, с учетом вероятностей дожития для шведского населения были модифицированы с целью учета меньшей ожидаемой вероятности дожития для групп онкопациентов по сравнению с вероятностью дожития для стандартных (практически здоровых) популяций. Это позволяет показать эффект, который оказывает модификация вероятности дожития для различных групп онкопациентов на пожизненный атрибутивный риск. Для расчета LAR модели риска EPA были применены к вероятностям дожития и данным по заболеваемости раком среди женщин (здоровые, рак молочной железы, рак прямой кишки, рак печени). Вероятности дожития в случае рака молочной железы высоки по сравнению с вероятностями дожития в случае рака печени.

Вероятность дожития до возраста а рассчитывалась как отношение числа живых индивидуумов возраста а к исходному числу на момент рождения. Вероятности дожития, специфичные для пациентов (например, с раком печени), $S(a)_{\text {Patspec }}$, модифицированы для первых пяти лет после облучения в соответствии с выражением:

$$
S(a)_{\text {Pat.spec }}=\frac{N(a)^{*}}{N(0)}=\frac{N(a) * A S P_{5}(\text { liver })}{N(0)}
$$

где $N($ a) и $N(0)$ - общее количество здоровых живых индивидуумов с учетом их пола в возрасте а и на момент рождения соответственно. $N(a)^{*}$ - общее количество живых пациентов в возрасте $a$, полученное умножением $N(a)$ на ежегодную пятилетнюю вероятность выживания пациентов с раком печени.

Результаты для пациентов с тремя различными раками представлены на рисунке 3. 


\section{Results and discussion}

\subsection{Changing the cancer base line and survival fractions of the LAR estimations}

A comparison between the LAR $\left(G y^{-1}\right)$ incidence for a Swedish male population, based on survival rates from the Swedish National Board of Health and Welfare [14] and the last 30 years of Swedish cancer statistic from NORDCAN [15] and for a US population is shown in Fig 2. Both estimates are based on risk predictions given by EPA [9]. All tissues received the same absorbed dose. For newborn, children and adolescents of the Swedish male population, the LAR is lower than for similar US groups. This is probably due to differences in cancer statistics. For adult and senior (60+ year) males, there is no significant difference between the countries. The impact of any differences in cancer statistics will be less for the elderly due to shorter survival.

\subsection{Changing LAR estimations from a healthy Swedish population to a cohort of Swedish patients}

In Fig 3 LAR $\left(G^{-1}\right)$ predictions are shown for a normal Swedish female population and for three different groups of Swedish female cancer patients. The LAR risks are the risk of receiving a cancer, incidence, for a cohort of breast, coIon and liver cancer subjects. All tissues received the same absorbed dose. The result can be interpreted in two ways. For colon cancer, patients who have a low probability of survival, additional diagnostic imaging would have a low impact. In some cases, examinations are performed on both normal (healthy) populations and a cohort of a specific (potentially diseased) patient groups with an average risk somewhere in between the risk for these two subgroups. Optimization tools would include as input the fractions associated with each of these groups.

\section{Conclusions}

In radiological diagnostics and therapy, it is important that practitioners and referrers (i.e., radiologists, radiation oncologists and other health-care professionals) understand the radiation doses and the associated risk for patients undergoing various procedures. The risk for radiation induced cancer should be known and considered for all types of medical exposures and patient cohorts, but unfortunately the knowledge among health care professionals is limited. There is a need to include both more valid assessments of absorbed dose, and reasonable estimates of induced number of radiation cancer cases that would occur later in life for specific patient cohorts.

The most commonly used quantity to estimate the stochastic effects (mainly cancer) in medical radiology is the effective dose (E). However, LAR estimates offer a more suitable and direct approach for assessing cancer risk from the exposure to ionizing radiation associated with medical procedures. For cohorts of Swedish patients, LAR values should be based on Swedish statistics on survival rates with adjustments to account for the patient's health status. Assuming the same absorbed dose for all organs, LAR coefficients $\left(\mathrm{Gy}^{-1}\right)$ for Swedish males were $0.11,0.068$, and 0.038 for ages at exposure 20,40 and 70 years, respectively; this is lower than the corresponding figures for US males, $0.13,0.077$, and 0.040 . For Swedish females exposed at 40 years of age with a diagnosis of breast, colon or liver cancer, the LAR coefficients were $0.064,0.034$,

\section{Результаты и обсуждение}

\section{Изменение фоновой заболеваемости раком и вероятностей дожития при оценке пожизненного атрибутивного риска}

Сравнение между значениями LAR $\left(Г \mathrm{p}^{-1}\right)$ для шведского мужского населения, основанными на вероятностях дожития, публикуемых Шведским национальным советом по здоровью и благополучию, и онкологической статистике NORDCAN, и для американского населения представлено на рисунке 2. Обе оценки получены по модели риска, разработанной ЕРА. Все ткани получили одинаковую поглощенную дозу. Для шведских новорожденных, детей и подростков мужского пола значения LAR ниже по сравнению с аналогичными американскими когортами. Это может быть объяснено различиями в онкологической статистике. Для взрослого и пожилого населения достоверных различий между странами установлено не было. Влияние любых различий в онкологической статистике для пожилых будет минимально в связи с более коротким периодом дожития.

Изменение пожизненного атрибутивного риска при переходе от здорового шведского населения к когортам шведских пациентов

На рисунке 3 представлены результаты расчета LAR $\left(Г \mathrm{p}^{-1}\right)$ для нормального шведского женского населения и для трех различных групп шведских онкологических пациентов женского пола. Все ткани получили одинаковую поглощенную дозу. Результат можно интерпретировать двояко. Для рака прямой кишки дополнительные диагностические исследования с применением ионизирующего излучения будут слабо влиять на радиационные риски в связи с тем, что у пациентов низкие шансы выживания. В некоторых случаях исследования будут проводиться как на нормальном (здоровом) населении, так и на специфической когорте (потенциально больных) пациентов, со средним риском, лежащим в диапазоне рисков для указанных когорт.

\section{Заключение}

В лучевой диагностике и терапии крайне важно, чтобы медицинский персонал (врачи-рентгенологи, лечащие врачи, радиационные онкологи и пр.) имели представление о том, какую дозу облучения получил пациент от различных рентгенорадиологических исследований и с каким риском для здоровья эта доза связана. Риски развития радиогенных раков должны быть известны и учтены для всех видов лучевой диагностики и терапии и для всех групп пациентов. К сожалению, знания медицинского персонала в данной области ограничены. Необходимо проводить более достоверные оценки поглощенных доз и оценку возможного количества случаев радиогенного рака, которые проявятся в дальнейшем у различных когорт пациентов.

Наиболее распространенным способом оценки стохастических эффектов (главным образом, рака) в лучевой диагностике является эффективная доза. Однако метод расчета пожизненного атрибутивного риска предлагает более подходящий и прямой подход к оценке радиационного риска при медицинском облучении. Для когорт шведских пациентов значения пожизненного атрибутив- 
and 0.0038 , respectively, which is much lower than the LAR coefficient (0.073) for a 40-year-old female without known cancer. Appropriate LAR predictions can help improved radiation risk estimates for normal (healthy) populations as well as for various groups of patients, and simplify the justification process for referring physicians as well as professionals in diagnostic radiology, nuclear medicine and radiation therapy. The information to patients will also be improved.

\section{Acknowledgement}

This project was funded by Swedish Radiation Safety Authority (grant number: SSM2018-2163)

Disclaimer:

The views expressed in this article are those of the author and do not necessarily represent the views or policies of their organizations. ного риска должны основываться на шведской статистике по вероятностям дожития с учетом текущего статуса здоровья пациента. Для шведских мужчин, при условии, что все органы организма получили одну и ту же поглощенную дозу, и облучение произошло в возрасте 20, 40 и 70 лет, соответствующие значения пожизненного атрибутивного риска (Гр-1) составили $0,11,0,068$, и 0,038 соответственно, что ниже по сравнению с аналогичными результатами для американских мужчин - 0,13, 0,077, и 0,040 соответственно. Для шведских женщин, при условии, что все органы организма получили одну поглощенную дозу и облучение произошло в возрасте 40 лет с диагнозом рака груди, прямой кишки или печени, значения пожизненного атрибутивного риска $\left(\Gamma^{-1}\right)$ составили 0,064 , 0,034, и 0,0038 соответственно, что существенно ниже значения 0,073 в случае облучения 40-летних женщин, у которых раковые заболевания диагностированы не были. Расчеты пожизненного атрибутивного риска могут повысить достоверность оценки радиационного риска как для нормального (здорового) населения, так и для различных групп пациентов, и упростить процесс обоснования для лечащих врачей и специалистов-рентгенологов, радиологов и онкологов. Информирование пациентов также существенно улучшится.

cer-risk-models-and-projections-us-population. (Accessed: 20.10.2018)

10. Berrington de Gonzalez A., Iulian Apostoaei A., Veiga L.H., Rajaraman P., Thomas B.A., Owen Hoffman F., Gilbert E., Land C. RadRAT: a radiation risk assessment tool for lifetime cancer risk projection. J. Radiol. Prot. 2012, 32:205-222.

11. NAS (National Academy of Sciences). Health risks from exposure to low levels of ionizing radiation. BEIR VII Phase 2. Washington, DC, USA: National Academy Press, 2006.

12. Andersson M., Eckerman K., Mattsson S. Lifetime attributable risk as an alternative to effective dose to describe the risk of cancer for patients in diagnostic and therapeutic nuclear medicine. Phys. Med. Biol. 2017, 62: 9177-9188.

13. Gudowska I., Ardenfors O., Toma-Dasu I., Dasu A. Radiation burden from secondary doses to patients undergoing radiation therapy with photons and light ions and radiation doses from imaging modalities. Radiat. Prot. Dosim. 2014, 161(1-4):357-362.

14. Swedish National Board of Health and Welfare. - Available from: http://www.socialstyrelsen.se/statistics/statisticaldatabase/help/causeofdeath (Accessed: 20.10.2018)

15. Engholm G., Ferlay J., Christensen N., Hansen HL., HertzumLarsen R., Johannesen TB., Kejs AMT., Khan S., Ólafsdóttir E., Petersen T., Schmidt LKH., Virtanen A., Storm H.H. NORDCAN: Cancer Incidence, Mortality, Prevalence and Survival in the Nordic Countries, Version 8.1 (28.06.2018). Association of the Nordic Cancer Registries. Danish Cancer Society. - Available from: http://www.ancr.nu (Accessed: 20.10.2018).

16. Critz F.A., Benton J.B., Shrake P., Merlin M.L. 25-Year diseasefree survival rate after irradiation for prostate cancer calculated with the prostate specific antigen definition of recurrence used for radical prostatectomy. J. Urol. 2013, 189(3):878-883.

Received: February 15, 2019 
Andersson Martin - PhD, leading researcher, Medical Radiation Physics Malmö, Department of Translational Medicine, Lund University, Malmö, Sweden

Eckerman Keith - PhD, senior researcher, Center for Radiation Protection Knowledge, Oak Ridge National Laboratory, Oak Ridge, TN, USA

Pawel David - PhD, statistician, United States Environmental Protection Agency, Washington, USA

Almén Anja - PhD, senior researcher, Medical Radiation Physics Malmö, Department of Translational Medicine, Lund University, Malmö, Sweden

Mattsson Sören - PhD, PhD(h.c.), professor, Medical Radiation Physics Malmö, Department of Translational Medicine, Lund University. Address for correspondence: Skåne University Hospital Malmö, SE-205 02 Malmö, Sweden; E-mail: soren.mattsson@med.lu.se

For citation: Andersson, M., Eckerman, K., Pawel D., Almén, A., Mattsson, S. Improved radiation risk models applied to specific cohorts of Swedish patients. Radiatsionnaya Gygiena = Radiation Hygiene. 2019;12(2):44-54. DOI: 10.21514/1998-426x-2019-12-2-44-54

\section{Литература}

1. Федеральный закон «О радиационной безопасности населения» от 09.01.1996 N 3-Ф3. Утвержден Государственной Думой 05.12.1995. - Москва, 1996.

2. EU. European Council Directive 2013/59/Euratom on basic safety standards for protection against the dangers arising from exposure to ionising radiation and repealing Directives 89/618/Euratom, 90/641/Euratom, 96/29/Euratom, 97/43/ Euratom and 2003/122/Euratom. O.J. of the EU. L13; 57: 1-73. 2014

3. ICRP. The 2007 Recommendations of the International Commission on Radiological Protection. ICRP Publication 103. Ann. ICRP. 2007, 37(2-4):1-332.

4. Harrison J. D., Balonov M., Martin C. J., Ortiz Lopez P., Menze H.G., Simmonds J.R., Smith-Bindman R., Wakeford R. Use of effective dose. Ann. ICRP. 2016, 45(1S): 215-224.

5. Almén A., Mattsson S. On the calculation of effective dose to children and adolescents. J. Radiol. Prot, 1996, 16: 81-89.

6. Wall B. F., Haylock R., Jansen, J. T. M., Hillier, M. C. Radiation risks from medical $\mathrm{x}$-ray examinations as a function of the age and sex of the patient. Report HPACRCE-028. Health Protection Agency, U.K., 2011.

7. Balonov M., Shrimpton C. Effective dose and risks from medical $x$-ray procedures. In: Proceedings of the First ICRP Symposium on the International System of Radiological Protection. Ann. ICRP 2012, 41(3-4): 129-141.

8. Balonov M., Golikov V., Kalnitsky S., Zvonova I., Chipiga L., Sarycheva S., Shatskiy I., Vodovatov A. Russian practical guidance on radiological support for justification of $\mathrm{x}$-ray and nuclear medicine examinations. Radiat. Prot. Dosim. 2015, 165: 39-42.

9. EPA. Radiogenic cancer risk models and projections for the US population. 402-R-11-001 pp 1-175, 2011. - Available from: https://www.epa.gov/radiation/epa-radiogenic-can- cer-risk-models-and-projections-us-population. (Accessed: 20.10.2018)

10. Berrington de Gonzalez A., Iulian Apostoaei A., Veiga L.H., Rajaraman P., Thomas B.A., Owen Hoffman F., Gilbert E., Land C. RadRAT: a radiation risk assessment tool for lifetime cancer risk projection. J. Radiol. Prot. 2012, 32:205-222.

11. NAS (National Academy of Sciences). Health risks from exposure to low levels of ionizing radiation. BEIR VII Phase 2. Washington, DC, USA: National Academy Press, 2006.

12. Andersson M., Eckerman K., Mattsson S. Lifetime attributable risk as an alternative to effective dose to describe the risk of cancer for patients in diagnostic and therapeutic nuclear medicine. Phys. Med. Biol. 2017, 62: 9177-9188.

13. Gudowska I., Ardenfors O., Toma-Dasu I., Dasu A. Radiation burden from secondary doses to patients undergoing radiation therapy with photons and light ions and radiation doses from imaging modalities. Radiat. Prot. Dosim. 2014, 161(1-4):357-362.

14. Swedish National Board of Health and Welfare. - Available from: http://www.socialstyrelsen.se/statistics/statisticaldatabase/help/causeofdeath (Accessed: 20.10.2018)

15. Engholm G., Ferlay J., Christensen N., Hansen HL., HertzumLarsen R., Johannesen TB., Kejs AMT., Khan S., Ólafsdóttir E., Petersen T., Schmidt LKH., Virtanen A., Storm H.H. NORDCAN: Cancer Incidence, Mortality, Prevalence and Survival in the Nordic Countries, Version 8.1 (28.06.2018). Association of the Nordic Cancer Registries. Danish Cancer Society. - Available from: http://www.ancr.nu (Accessed: 20.10.2018).

16. Critz F.A., Benton J.B., Shrake P., Merlin M.L. 25-Year disease-free survival rate after irradiation for prostate cancer calculated with the prostate specific antigen definition of recurrence used for radical prostatectomy. J. Urol. 2013, 189(3):878-883.

Поступила: 15.02.2019 г.

Андерссон Мартин - кандидат биологических наук, ведущий научный сотрудник, Группа медицинской физики отдела трансляционной медицины Лундского университета, г. Мальмё, Университетский госпиталь округа Скона, Швеция

\section{Маттссон Сорен}

Группа медицинской физики отдела трансляционной медицины Лундского университета, Университетский госпиталь округа Скона Адрес для переписки: ITM, Lund University, Skåne University Hospital Malmö, SE-205 02 Malmö, Sweden; E-mail: soren.mattsson@med.lu.se 
Эккерман Кейт - кандидат биологических наук, старший научный сотрудник, Центр данных по радиационной защите, национальная лаборатория Оук Ридж, Оук Ридж, Теннесси, США

Павел Девид - кандидат биологических наук, статистик, Агентство по защите окружающей среды США, Вашигтон, округ Колумбия, США

Олмен Анья - кандидат биологических наук, старший научный сотрудник, Группа медицинской физики отдела трансляционной медицины Лундского университета, г. Мальмё, Университетский госпиталь округа Скона, Швеция

Адрес для переписки: Маттссон Сорен - кандидат биологических наук, профессор, Группа медицинской физики отдела трансляционной медицины Лундского университета, Университетский госпиталь округа Cкона. (ITM, Lund University, Skåne University Hospital Malmö, SE-205 02 Malmö, Sweden; E-mail: soren.mattsson@med.lu.se)

Для цитирования: Андерссон М., Эккерман К., Павел Д., Олмен А., Маттссон С. Улучшенные модели оценки радиационного риска для отдельных когорт пациентов в Швеции // Радиационная гигиена. - 2019. - Т.12, № 2 - C. 44-54. DOI: 10.21514/1998-426X-2019-12-2-44-54 